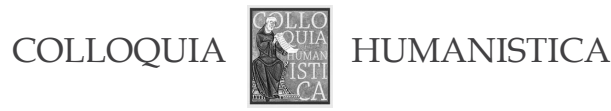

\author{
Maciej Falski \\ Institute of Western and Southern Slavonic Studies \\ University of Warsaw \\ Warsaw
}

\title{
Continuity and Discontinuity in the Cultural Landscape of the Capital City: Paris and Skopje
}

\begin{abstract}
Ontinuity and change are fundamental aspects in the functioning of every culture. The best exponent of cultural continuity is tradition. We may name tradition that which has value for a group and that which serves as this group's positive or negative point of departure; thus, in any given historical context, tradition shall be what has been reaffirmed from amongst an inherited past. But here not only the question of memory is relevant. In the above definition, itself obviously a reduction, two aspects are relevant, both of which will be discussed below, namely the axiological aspect and the conceptual aspect. Tradition, memory, and as a result, cultural continuity, are linked with a group's core values, these being an important, perhaps even the most important, aspect of the life the members of the group have in common. Secondly, reaffirming some things out of a wider inherited past presupposes an element of choice, and thus the active creation of a vision of the past dictated by the needs of any given situation, the dictates of currently functioning values. Political context is of fundamental significance in the formative processes of historical narrative. Narrative, or the common story of the past, places the community in time and space, and equally importantly, gives it a sense of purpose, rootedness, and longevity. History acquires meaning, undergoes organization, and thus the group becomes aware of its place in the historical scheme. This then affords the social unit the soothing sensation of participation in a collective identity afforded by a purpose-endowed vision of the past. ${ }^{1}$
\end{abstract}

1 The issue of tradition and the creation of a vision of the past accumulated a rich bibliography. Here I reference the still-useful approach of Szacki (1971). On the usefulness of narrative categories in the definition of identity and group plans, see Falski (2008a) and the references contained therein. 
Narrative comes about in a particular context; it is self-evident that no story is timeless or unchanging. The power of interpretation lends force to the formation of meanings and the creation of much-wanted foundations. The control of social imaginations, particularly those concerning tradition and identity, is a crucial stage in the political shaping of any vision of the past. It would be interesting to analyze the process of constructing desired significations, and concretely, the deployment of foundations into the past in democratic societies, or rather, speaking more precisely, in pluralistic societies. The situation of the totalitarian state appears obvious enough: one central authority controls the realm of imagined practices and submits to its influence the entire discourse. Meanwhile the meaning-creating practices of pluralistic societies with scattered sites of power do not provide clear answers to the question of how to obtain the desired result-how to generate the most effectively the intended vision of the past, tradition, and identity, in the realm of social communication.

The organization of social time, the provision of a form of narrative coherent to its course, is one of the most basic activities of the individual and the group. A second, and equally vital, activity is the organization of space, the creation of an order that gives a sense of safety and control over one's existential situation. However the basic criterion of the spatial order is not so much convenience, or economy, or the desire to take advantage of the physical landscape. The cultural landscape is above all a social landscape, where, aside from physical configuration, social relationships as well as symbolic practices have an important role to play. The cultural landscape, the environment in which all individuals are, is a realm of the senses, of signs, and of symbols; and whether these succeed to communicate depends upon the competence of participants in public life.

The object of my reflections in this article is the question of creating a vision of historical continuity, and thus making significant the narratives about the past, in the space of the city. I treat the city as a cultural landscape par excellence; it is precisely the city that creates the best opportunities of influencing interpretation by means of creating a specific set of symbolic references and of images awakening the play of interpretation. Just as important is the fact that the city is inhabited by many individuals and varied groups, which forces it into negotiations of signification; cities, finally, are most frequently an auditorium for the activities of the authorities, who attempt to impose upon the city whichever interpretation they may prefer. ${ }^{2}$

A particularly promising object of study for the concept I have sketched

2 The problematic of urbaneness and the social dimension of city space have an equally rich bibliography. I rely here primarily on the work of Ulf Hannerz (Hannerz 2006) and Jałowiecki and Szczepański (Jałowiecki, Szczepański 2006; cf. Jałowiecki 1988). 
out appears to be the capital city. The capital of a nation state is a specific city, normally defined by its very legal status as capital, recognized and regulated by special edict. Here are located the main state institutions, this is the seat of legislative, executive, and judiciary power, here the representatives of other nations and international legal subjects have their residences, here are as well the principal institutions of economic and scientific life of the state. The capital is finally a symbolic space of particular weight: here is where the majority of public demonstrations of nationwide importance take place, and it is also one of the main destinations for educational excursions and patriotic pilgrimages. This is a true calling card of a country, an important link in the social network-so there is nothing too shocking in the suggestion that it is precisely the landscape of the capital that becomes the locus of the struggle for meaning, the writing of the narrative that will prescribe the meaning desired (Falski 2008b). Architecture and urban studies may propose specific ways of generating significance by using their own disciplinary traditions (cf. Raulin 2001). This very process of creating a narrative of continuity and tradition in the capital landscape will be the main topic of this article. I have selected cities that for many reasons are very different: Paris and Skopje. Based on these examples, I would like to show the specific ways of drawing conclusions adapted to the urban landscape, because despite the obvious differences, both cities allow for the discernment of a historical period in which the city itself served as an important element of the public realm and as symbolic public property. The increased significance of cities in Europe is connected without a doubt to the process of democratization, thus the capitals of France and Macedonia are good examples of the transformation that converted a privatized (feudal) space or a space interpreted along sacred lines (as land belonging to God) into a public space and public property to be shared by citizens, and/or exercising control over the nation.

The capital as a main center of the state and more often, in Europe, as the main center exercising control over the nation within the state, actually begins to play this type of role in the time of the French Revolution. This process correlates with and is genetically related to the formation of modern nations as well as of industrial societies. Paris at the end of the eighteenth and the beginning of the nineteenth century may be recognized as a paradigm of these transformations. Before Paris became obviously the main city of the kingdom of France, and its parliament the main voice in political debates, the seat of the royal throne was the political and symbolic center. Versailles, established by Louis XIV, was supposed to be the emblem of monarchic autocracy. The Versailles-Paris dichotomy was abolished by the process of democratization, and the capital on the banks of the Seine became, in the nineteenth century, the primary arena for political and social 
debate impacting the situation of the entire state, and later of the colonies. It was here, too, that all the important state institutions made their homes, first and foremost among them, the parliament. The capital, in fact, became an unusually important symbolic space, a place for the demonstration of state and national strength, the expression and assertion of identity, the presentation of an image to outsiders as well as the formation of the desired image for the use of the citizens/property owners. Earlier, the throne had been the emblem of power and authority (real and symbolic), which could have been situated at Versailles just as easily as at the Louvre in Paris; the city belonged, after all, first and foremost to the realm of the local and the regional. The bourgeoisie, the peasantry, and the aristocracy were divided by a nearly impenetrable barrier of local membership, but what united them into a single body was the authority of the king. Democratization changed this manner of conceiving the social system; the capital city became a national public property with particular value to all. As a result of this, the capital city also attained an important place in the process of shaping desired values, and from this perspective, too, an investigation into the question of cultural continuities and discontinuities in this delimited space is essential.

Skopje presents a distinct object of focus for this inquiry into the status of the capital of a democratic nation and of the main center of a nation; after all, the point of departure in the processes of modernization was different than in the case of Paris. In the Ottoman state, theoretically, the sultan was the owner of the land and the person in charge, and he embodied the unity of the state. Organizationally the empire was divided into districts connected with the administration of the army (vilâyet/eyâlet); meanwhile from a legal and social perspective the functional units of division were denominational formations (millet). The most important divide occurred between Muslims and non-Muslims, which meant that the question of nationality was not felt to be of utmost importance for a long time. For Islam, the main center was Mecca, which was the center of the world, and also Istanbul; the gradual rise in emancipatory movements amongst conquered nations led to a rise in significance of local urban centers. ${ }^{3}$ Skopje was the capital of the Kosovo vilâyet after 1864 , an important strategic city, but it did not play a particularly prominent role and its influence declined. ${ }^{4}$ Nor was it the center of the Macedonian national movement, attaining that status only after the World War 2. Then, in any case, the city on the Vardar became linked with the Karadjordjevic monarchy; it became the capital of the republic of

\footnotetext{
3 About the Ottoman city, the millet, and a general characteristic of the Ottoman Empire, cf. Inalcik (2006); Jelavich (2005); Castellan (1992); Rossos (2008); Lewis (1984).

4 Cf. Rossos (2008: 67) who states also that "parts of geographic Macedonia lay in three vilayets, which also comprised some non-Macedonian areas."
} 
Macedonia and the central headquarters for Macedonians only after 1945. Yet despite the various differences here, a process of democratization and a broadening of the control of space are also evident. The old Ottoman city is one of many autonomous organisms, the community formally submits to the control of the sultan as well as his laic supervisors, enjoying an internal order distinguishing it from neighboring rural areas, always symbolically oriented, however, toward Mecca-or toward other centers in the case of non-Muslim denominations. Change was brought about only by the gradual nationalization of space, the recognition of it as property belonging to the whole nation, which was accompanied by the real and declared liquidation of vertical divisions and the creation of an imagined community embracing all the members of the nation (Gellner 1991; Anderson 1997). I thus argue that Skopje, too, is a good example of a capital landscape that became a space for the demonstration of national values and the principal site of their reproduction.

The essential aim of this article is to perceive the basic outlines of the image of the French and Macedonian national traditions on the basis of an analysis of continuities and discontinuities in the landscapes of the capitals of both states. I propose that it is precisely the landscape of the capital city that will reflect the dominant perception of its own tradition in the dominant group in that state, and thus, in the case of France and Macedonia, in a pluralist nation. In Paris, or even in Skopje, the main actor's function-the effecting subject, decision-maker and initiator of actions-is assumed not only by local authorities but also by state authorities, appearing as representatives legally binding the entire nation. ${ }^{5}$ The return of the king to Paris, and then the foundation of a permanent seat for national gathering in that place, can be seen as a symbol of national unity as well as of the democratic character of the state. Meanwhile, the tradition of the monarchy, despite its apparently total negation, still remains one of the dominant factors in the collective imagination of France, which I attempt to demonstrate in a later section of this essay. As a result of revolutionary activities many buildings were destroyed, along with their furnishings (including the Bastille, the Abbey of Saint-Denis outside of Paris, as well as other sacred sites), or their purpose shifted (as in the case of Pantheon), but the urban arrangement was preserved. The real revolution in the network of streets and squares was brought about only by the rebuilding of the French capital conceived and executed in the 1850's and 1860's by Haussmann under the auspices of Emperor Napoleon III. Two ideas guided this process: sanitization and rationalization. The basic plan involved the destruction of much of what was

5 I employ the term actor after Wnuk-Lipiński (2008). 
then in place. Marked for demolition were mostly those buildings deemed hotbeds of sickness, damp places, insanitary places, obstacles to fluid traffic; in large part these were areas still preserving medieval layouts of streets and alleys with densely concentrated buildings, often with small rooms with no plumbing or electricity. This kind of architectural order really did not suit the idea of hygiene and the increasing awareness of the etiology of illnes-

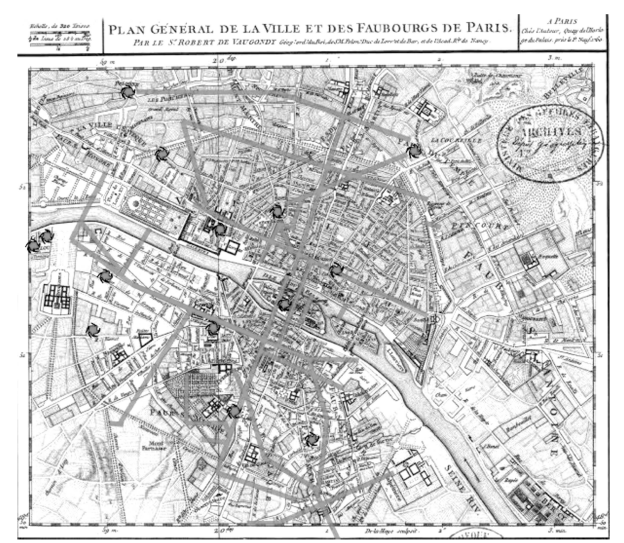

Fig. 1. The plan of Haussmann's arrangement of Paris ses, nor was it compatible with the prestige of Paris as a world metropolis.

The second stimulus was the desire to modernize the urban arrangement and make it suitable to the changing conditions of an industrial city. The increasingly sprawling city absorbed the localities surrounding its center, uniting them into a not entirely coherent whole, where each district would preserve its own network of streets and alleys oriented around local centers of transportation but only barely communicating with other parts of the city. Convenient lines of transportation suited to the needs of growing street traffic were also lacking. The next problem was posed by the necessity of new connections between the remainder of the train stations in the center of the city and the other districts, a necessity which had obviously not been foreseen by the old city planning. And finally, not without significance was the striving of Napoleon III toward the creation of transportation conditions that would allow, in the case of a popular uprising, for the city to be reinforced by the army in order to stifle protest. After his experiences in the July revolution of 1848, which led to the overthrow of the last king of France, Louis Philippe, the ruler realized the power of the crowd and wanted to seize the opportunity of gaining the most effective way of pacifying the citizens of the capital. And so it was to serve this goal, too, that a network of wide, concentric boulevards, connected by the newly demarcated arteries, was built.

The restructuring was undertaken on a truly enormous scale - it is estimated that around sixty percent of preexisting structures were destroyed. This unprecedented and bold treatment of the given space (l'espace donnée $)^{6}$ may be read not only in the practical dimension about which I spoke above, but also in the symbolic. Haussmann's Paris was

6 The operational value of ideas of given space and created space is set out in Bromberger and Ravis-Giordani (2003). 
supposed to be a modern metropolis, the capital of a world state and the main center of a modern nation. The total restructuring signified the final break with the old establishment, embodied in the urban landscape by two main types of architecture: the palace, the residences of the aristocracy, and then the alley, the place where common people came to be. The new Paris was supposed to be a city of the new class - the bourgeois, aware of its own status. This was when the bourgeois house came into being, with its typical internal structure (from the ground up, a shop or a workshop, then the areas occupied by the family of the owner, then the rented apartments and finally the servants' quarters) as well as its external structure (uniform facades, regulated by building rules in effect across the entire city of Paris down to the smallest details). This rupture with urban continuity I interpret, firstly, as the final, physical proof of the triumph of political movements from the end of the eighteenth century striving toward breaking with the old order (l'Ancien régime), the real and symbolic recognition of the supremacy of the new class that had arisen with the demise of the old state order. ${ }^{7}$ Secondly, this was also a recognition of the cultural change apportioned by industrialization and the new kind of economy relying on industrial production and capitalism. The new society demanded an altered organization of space that would be suitable to the new kind of practices associated with altered lifestyles, with mobility, with the organization of the day. For these reasons, the restructuring, symbolized by Baron Haussmann, has all the characteristics of a gesture of breaking with cultural continuity.

However despite the rebuilding of the heart of Paris, the islands with the Notre-Dame Cathedral and the Louvre remained. These historic buildings, testifying to the former power of the city, to French dynasties and to the state itself, served as the center not only of urbanization, but also gradually the center of France itself (Deutsch 2009). What's more, in Haussmann's time the principal perspectival and transportation axis of the capital was maintained and reinforced, namely the course of the big boulevards from Place de la Concorde to Place Charles de Gaule-Étoile; these are the best-known, most representative streets of Paris: the ChampsÉlysées and the Grand-Armée. That axis connects two unusually distinct symbolic points: the Louvre and the Arc de Triomphe. The Louvre during the Ancien Régime was of course the site of the throne. However under the Republican government, and then the empire and the later changes its royal connotation was not so obvious. The well-preserved castle was made into a museum as well as other publicly useful institutions. Thanks to that

\footnotetext{
7 On the paradox that it was the emperor who initiated this: and fora, fantastic description of the rebuilding of Paris and its social ramifications in Émile Zola's novel cycle the Rougon-Macquart, see especially Au bonheur des dames first published in 1883.
} 
it lost its uniform royal connotation, becoming rather a symbol of French statehood, and thus a symbol of identity. Modern France, founded upon the myth of the revolution, rejects immediate positive valorization of its royal past, without giving up, however, its image of its European, or even world power in political, economic, and military terms. The immediate connection to these very images is the Arc de Triomphe at the Place Charles de Gaulle. Imagined by Napoleon I as an allegory for his own triumphs, it was completed only later in 1836, becoming an allegory for the power of France. After World War I a tomb for the Unknown Soldier was slated to appear here, which completed the process of nationalizing the symbolic structure of the principal axis of Paris and which emphasized the national, rather than individual character of the monument itself. Here the nation, as Benedict Anderson writes, honors itself (Anderson 1997). The Louvre-Arc de Triomphe axis symbolizes therefore the continuity of French statehood, regardless of regime, the domination not only of the nation but of a powerful nation and state.

The identification of the nation with the state is the foundation of the modern conception of the nation as well as of international order in Europe. On the basis of the remarks made thus far we can add to that pair a narrative justifying that connection, ordering the past from a certain perspective. The significant space of Paris reveals very clearly just such a connection; without the support of the past there is no stronger national politics, nor can the nation exist fully without "its" state. The nineteenth century was a time of nationalization for the space of Paris, connecting it to the general system of the imagination and practices of the nation as such. The city was no longer just the domain of its residents nor of the bourgeois establishment; it had become a capital, and along with that the main center for decisions affecting the entire state, as well as the exponent of historical politics and the politics of governing symbols. The capital on the Seine reveals agreement with regard to the constitutional values of modern France: amongst them were, without a doubt, statehood and the idea of empire.

The main axis of the grands boulevards affirms the transformation effected by the Haussmann restructuring of Paris; symbolic force was attained by the class with the most social capital at the time, the bourgeoisie and its elites. The supremacy of the new class was established by the processes of democratization despite episodes of monarchy. The modern epoch is characterized by the related identification of nation and state at the giving up of ideas of monarchy, and thus of a social order founded upon God's will (the idea of the king as anointed by God). I believe that it is this transformation, the provision of a state and national character of the tradition that is revealed by the transformations (discussed above) in 


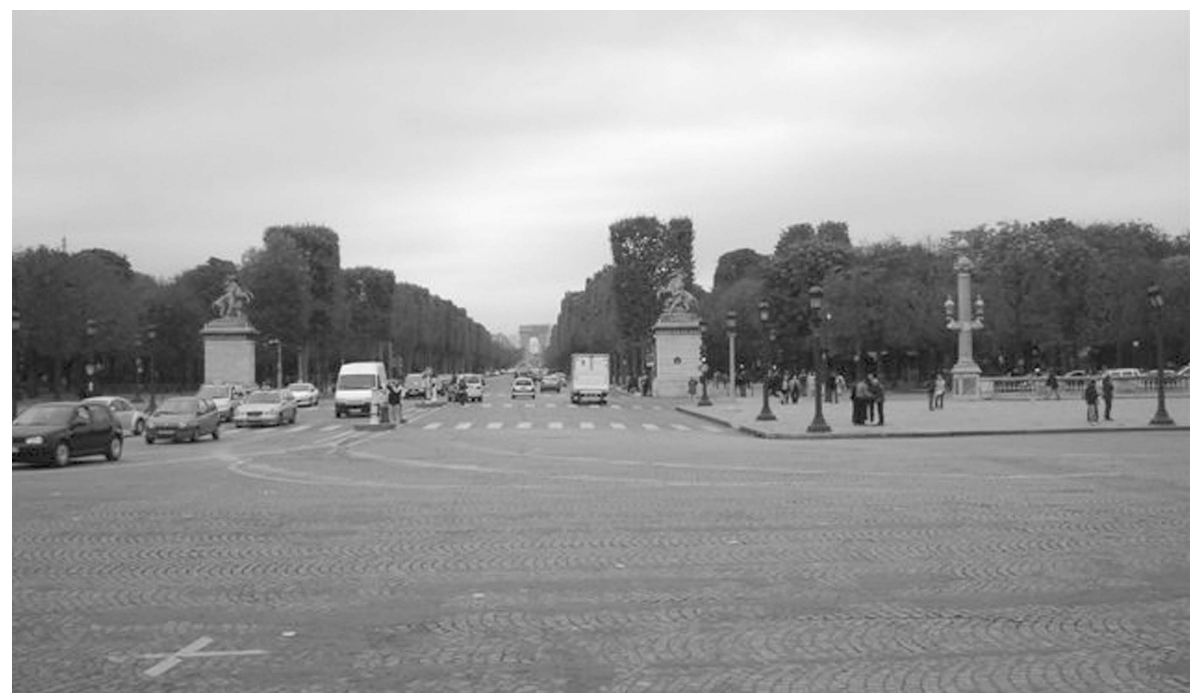

Fig. 2. The main axis of Paris, Avenue des Champs Élysées, view from Place de la Concorde on the Arc de Triomphe (photograph by M. Falski)

the urban fabric of Paris that took place between the era of Napoleon III and 1918. The urban landscape of the French capital was thus shaped by a dialectic of continuity and change that established a modern identity. The sites of continuity, in fact the primary orientational points, were not destroyed, like the Louvre, the Tuileries Gardens, the Pantheon, but they did acquire new meanings as symbols of the state, rather than of the regime.

The transition from an industrial economy to a post-industrial economy, as well as the ceaseless necessity of modernizing the structures of the city, reflect an interesting process that poses questions about the identity of that city. A response to the needs of the changing economy in large cities all over the world is the creation of business districts, concentrating subjects responsible for management, the flow of capital, research, but not production, which is transferred to the outskirts of the city or to Asian countries (cf. Castells 2009). A characteristic element of contemporary cities has become the multi-story office building, maximizing investment return but also providing economy of transportation. Their elevation, most often in a strikingly visible way, contrasts with the structure of European cities because they attain the most important directives of modernist functionalist aesthetics: divested of decorative elements, with clean, straight lines, made of glass, artificial materials, concrete, and monolithic steel, separating them from the compact and most often historical architecture of old city centers. Agglomerations of office buildings destroy the harmony of the city's structure first and foremost with respect to the proportions that do not correspond to 
the individual dimensions basically preserved up until that point. Meanwhile in Paris, until recently one of the most important economic and political centers in the world, there is very little of that type of construction. The most characteristic and criticized is the Tour de Montparnasse. Of course we must mention two emblematic buildings of Paris, the Eiffel Tower and the Georges Pompidou Center. They became symbols of the city, even though they aroused very strong objections among the residents and authorities of the city; they became over time to a large degree also a symbol of the French esprit and the ability to surprise with bold solutions. Meanwhile the business district was implemented outside the bounds of Paris.

The neighborhood of La Défense is located several kilometers outside of the city and the Arc de Triomphe, on the boundaries of three municipalities: Nanterre, Courbevoie, and Puteaux. The decision that it would be built, as well as the first efforts to put this into effect occurred back in the 1950's. A dozen or so skyscrapers were erected there, an underground train, bus, and metro station, a large shopping center, as well as smaller constructions were built. The best-known structure is the Grande Arche de la Défense, inaugurated in 1989. It was placed on the axis of the grands boulevards, connecting the center of Paris (the Louvre and the Place de la Concorde) with the Arc de Triomphe. The boulevards were extended further in the direction of the new district, and their closure is in fact the Grande Arche. Such a composition achieves perfectly the symbolic aim it was intended to fulfill. The Grande Arche is the multiplication of the Arc de Triomphe, its own particular repetition in a new location; a construction connected with the economy attained in this way an aesthetic and symbolic dimension, somehow testifying to the power of the French economy, but in an aesthetic sense. Secondly, this building closes the panorama of the Grands Boulevards from the Place de la Concorde very well, while a viewer from the foot of the Grande Arche in La Défense sees very clearly the perspectival and transportation axis, reaching into the heart of Paris and of France. I believe that in this way the symbolic structure discussed above has been reinforced. In the first place, made evident are images of the continuity, statehood, and mightiness of France. Continuity I put first because the lengthening of the primary axis of the capital connects three symbolic places and periods: the royal (the Louvre), the republican and Napoleonbased (the Arc de Triomphe), and the modern based firstly upon economy and politics (the Grande Arche). I speak, too, of statehood, because in my opinion the regime-in spite of the solemn republicanism of the Frenchplays here a secondary role in the idea of the existence of a (strong) state; in any case the history of France is in principle from medieval times the history of reinforcing the royal domain and broadening judicial power. And finally the idea of mightiness, which is linked with monumental and spectacular 


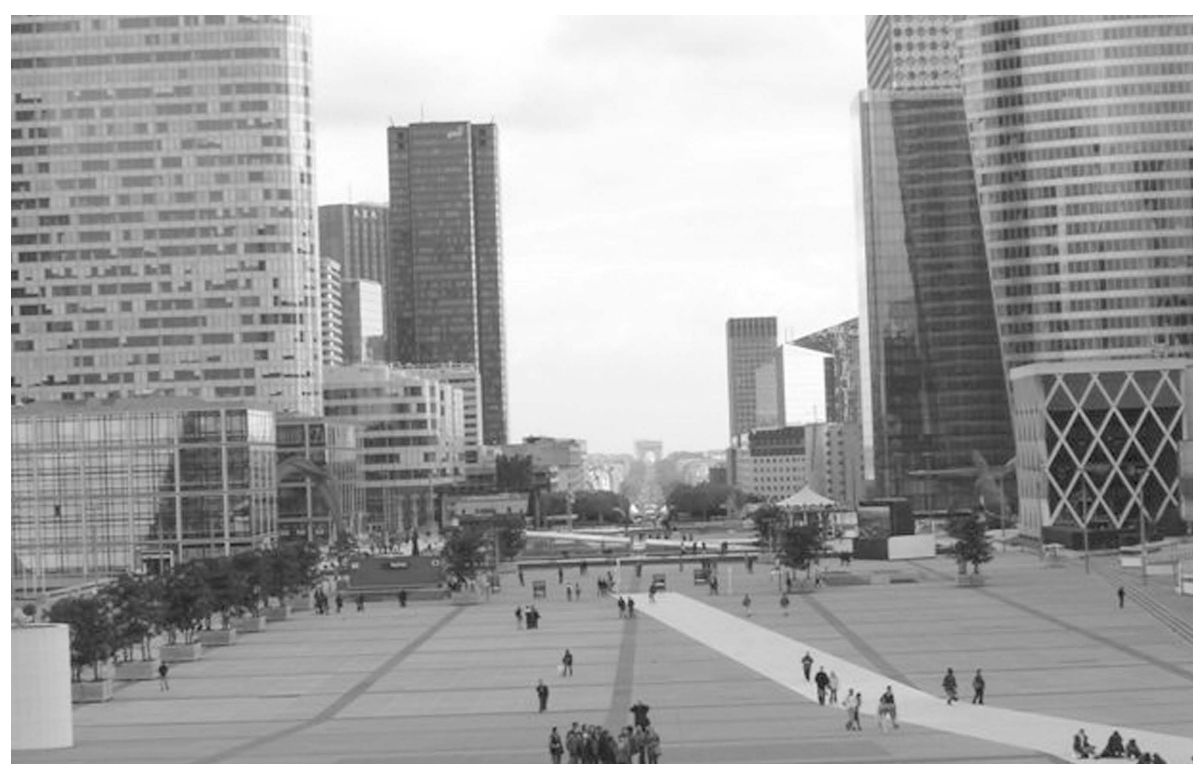

Fig. 3. The view from La Défense over the main axis and the Arc de Triomphe (photograph by M. Falski).

accomplishments with respect to their size and functions. The panorama itself urges the onlooker to think about a space that is expansive, well expressed, and conscientiously organized around the three city emblems.

The decision to situate the modern new district beyond the boundaries of the capital had a twofold motivation: the main purpose was to maintain the

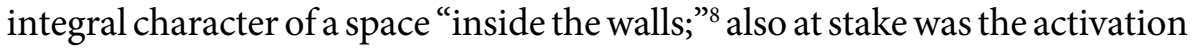
of thus-far neglected suburbs. The care about urban and architectural Paris comes from the nationalization of the space of the city, now treated as a space for the demonstration of the values discussed above. Now, along with the establishment of the new business district, that space was extended and gained symbolic support. The decisions of the authorities can be seen as a desire to maintain the local (Parisian) district and the national (capital) district in an unchanging state. There seems to be also a desire to preserve the monumental, emotional, and ecological value of the most important city in the country, a refusal to recognize the dominance of pure market capitalism, which might have inclined some toward construction in the city proper. Along the same lines the politics of city planning would aim at the assertion of the exceptional character of the capital of France, and thereby the exceptional nature, too, of the French national character, placing cultural values (monumentality, heritage, aesthetics) over profit. It is thus

8 „Intra muros,” as Parisians frequently say. 
evident how the dialectics of continuity and discontinuity still shape the Parisian landscape, ceaselessly updating constitutive values. The planning of the urban order becomes one of the most important instruments in shaping the imagination and self-stereotyping, and also, in consequence, and accordingly, their visualization for the sake of "its own" and "outsiders."

The process of modernization in Skopje evolved from a completely different situation than what was described above. The disparities are obvious: a different political system, a distinct social and cultural situation, and a much smaller number of inhabitants. Skopje was only just entering the era of industrialization at the end of the nineteenth century, it was not the capital, but rather one of the many European city centers in the Ottoman Empire, and thus it served as a local center, rather than a global center like Paris at that time. As a result of this there was not a single dominating actor that would require the shaping of the common political space, that would express a certain intentional social order, at once practical and meaningful. The Islamic city manifested far-reaching conservatism with regard to the organization of the spatial order. Traits typical to it included the division of residences according to denomination (which is to say, segregation); the existence of an administrative district in which were concentrated the seats of the most important city administrators; the charshiya, or the city center, containing service, manufacturing, and business activity-the district of craftsmen and merchants. In the Ottoman city the principal sponsor with regard to public institutions was not the state; private foundations dominated, imarets connected with charitable activity, financed most often by Waqfs. Essentially there was no public space aside from marketplaces and the areas around the mosques. The basic unit of segmentation was the municipality (džemat) concentrated upon its mosque. The Ottoman city was a space of diversity tolerated by the central authorities; fidelity to dynasty and state were in fact the only ideas connecting into a whole the outstretched networks of concatenations, institutions, and groups (Inalcik 2006). It was only at the turn of the twentieth century that the Turkish idea was introduced into Ottoman state, crystallizing and becoming visible, as well as the functional reliance of the country upon the foundation of nationhood; however conditions were such that the idea was not translated into the foundations for the urban landscape. Skopje of that period represents a typical construction model of a city in the European portion of the Empire.

The situation changed after World War I. As a result of the second Balkan War, from 1918 on, Skopje and Macedonia found themselves in the Kingdom of Serbs, Croats, and Slovenes (the Kingdom of Yugoslavia after 1929). A new actor appeared in the Macedonian landscape that had a crucial impact on the program and shape of construction in those years: the state. The Vardar 
Macedonia, or officially South Serbia, was located within the realm of Serbian influence, thus the interwar construction agenda was connected primarily to the image of the reigning new dynasty (Karađordevic) as well as to the new center of power, which was now Belgrade rather than Istanbul. Several public service buildings, established in central places in the city, testified to the striving of the new authorities toward the management not so much even of a factual landscape as of a symbolic realm. The imposition of a new order had to rest upon two pillars of state identification in interwar Yugoslavia: dynasty and army. Near the central square crucial landmarks arose: the Army House (Офицерскиот дом), the Christian Orthodox Church, the National Theatre (Народниот театар), and the National Bank (Народната банка). ${ }^{9}$ Particularly the church had a double significance, emphasizing the domination of Christianity in the changed conditions of political affiliation of a city previously dominated politically and (to a certain degree) legally by Muslims, but also providing a sign of presence of the Serbian Orthodox church, which subordinated the territory of Vardar Macedonia to the SCS Kingdom. It did not come to systemic alteration in Skopje, however, as it had in Belgrade and other Serbian cities after 1866, when the Turkish presence in the territory of the jurisdiction of an autonomous principality came to its end. At that time the fully appointed authority of the Christian state made possible the undertaking of a significant reconstruction of the urban layout and architecture of Serbian settlements; the goal of this was firstly to wipe out all traces of Ottoman presence in the region. The appropriation crossed over from the political and legal realm into the symbolic. The city landscape was made into a primary field of transformation, an eyewitness to the end of the old establishment where were introduced new points of orientation for the mental map of inhabitants of the Balkans (Jezernik 2006; Đokić 2004). In Skopje, however, it never came to such a violent metamorphosis. Although the Balkan wars and the treaty after the World War I brought about an agreement on the exchange of populations between Serbia (later the SCS Kingdom) and Turkey, as a result of which a significant portion of the Muslim population left Macedonian areas, the Muslims still accounted for a large percentage of residents of Skopje (Stawowy-Kawka 2000).

The likely reason for interference into the landscape of the city was the lack of any actor with an interest in reconstruction with the purpose of generating a new symbolic order. In Haussmann's Paris and post-Ottoman Serbia this role was played by the state-understandably so, if one considers the two most important planes of initiation of urban action, the financial and the symbolic. Changes to the network of streets and squares, tearing down

9 These objects were not rebuilt after 1963, and their reconstruction was considered in 2006, see below. 
entire quarters and putting in constructions obviously demand considerable financial outlay, very difficult for a city without the support of a centralized budget. Paris and Belgrade are capital cities, and for this reason, they aroused particular concern on the part of the ruling elite, who had an interest in the representative and symbolic shape of these centers. Meanwhile Skopje in the SCS Kingdom and the Yugoslavian monarchy had no such character, thus shaping its image could not have become a question of utmost importance on the scale of the whole state. Furthermore, it was the main city of a politically ambivalent region. The official Serbian position after World War I negated the existence of a Macedonian nation and discouraged any emancipatory efforts made by Macedonian Slavs. The Vardar River region was called South Serbia, and its main center was seen above all as the medieval capital of the empire of the Serbian ruler Stefan Dušan. Infrastructural reinforcement of Skopje was not in Serbia's interests, at least up until the time of the successful assimilation of the population of Vardar-region Macedonia. In that period settlement campaigns were also funded, encouraging residents of ethnic Serbia to settle in Macedonia. Above all these actions allowed the city to maintain its post-Ottoman character without going through a period of violent "Europeanization" like the capitals of the newly created (from 18781908) other Balkan states (Belgrade, Bucharest, Sofia).

The rebuilding of the Macedonian capital was somehow forced by a natural disaster - the earthquake of 1963. This had dramatic effects on the city; around 90 percent of the city was destroyed, and over of a thousand of its inhabitants perished. The colossal scale of the tragedy led to immediate aid campaigns from around the globe, but at the same time it forced the city and state authorities to make a decision about the form of the rebuilding. The authorities decided

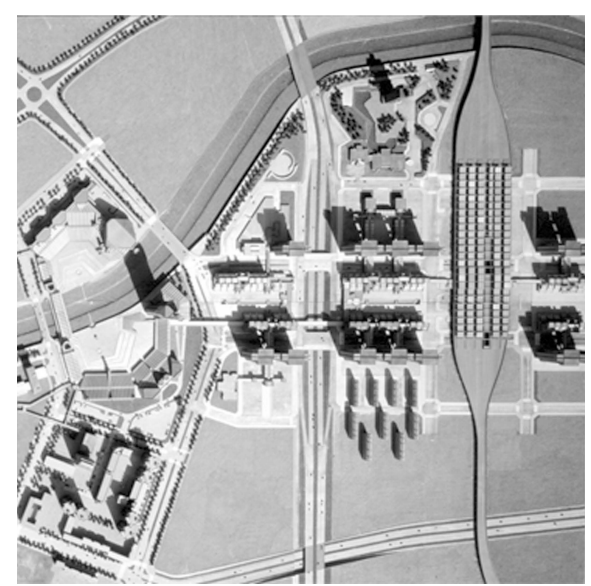

Fig. 4. The Kenzo Tange's model of the new centre of Skopje (source: http://www.europelostandfound.net/node/97) on a bold solution, namely, the nearly total reconstruction of the city center. Architects and urban planners from all over the world took part in a competition for the job, and a Japanese architect Kenzo Tange won. His plans were not realized in their entirety, which deprived Skopje of a coherent layout.

The main precept of that winning plan had been modernization, understood here as accessing the newest trends in architecture and urban planning as well as correcting the functionality of the central districts, 
both residential and public. The components and facades of the buildings to be erected according to that plan favored modernist strategies. They bore no resemblance to local strategies, breaking completely with historically connected styles or symbolic forms of the European-Islamic border region. Visual continuity in the representative portion was shaken as the center was to a great extent not so much rebuilt as built entirely from scratch. It was decided, however, to preserve the charshiya, the district typical of cities of the Ottoman tradition, mosques and other monuments also remained. ${ }^{10}$

The decision to rebuild was made in a new political context. Macedonia had attained independence and was one of the subjects of the Socialist Federal Republic of Yugoslavia, the existence of a separate Macedonian nation was also recognized. Skopje after 1945 became the capital of an autonomous republic, as well as the center of Macedonian national life and the site of the main institutions affirming national identity. The question of organizing the urban landscape of the capital became important both politically and socially. Rebuilding the center could have been read, then, as choosing a new road that would suit Macedonia's new national status and the new epoch in its history begun some two decades before. Choosing the option of modernization was also a sign of the maturity or the modernity of Macedonian culture itself. The possibility of changing its image came into being-an image that had previously been connected with the Balkanness, populism, and immaturity of the elites. It was precisely that kind of option that was suited by the calling up of an international team of urban planners and architects. In the Macedonian situation, then, paradoxically, it was a noticeable discontinuity in the city-space that provided the affirmation of an imagined national community, and not continuity and the preservation of the urban field. The change would in this context have been the equivalent to starting a new narrative, breaking with the colonial legacy and subordination to the Ottoman Empire as well as with the Serbian monarchy. A new Skopje would have been, then, a sign of the new Macedonian culture, restocked with an elite level and open to the world.

Skopje and Paris (without forgetting their respective scales) responded differently to trends and to the demands of urban and economic modernization. I believe that locating of the district of La Défense beyond the bounds of the city while simultaneously connecting it along the perspectival axis with the central symbolic and orientation points of Paris allowed for the reinforcement of important threads of the French national narrative; at the same time the construction needs resulting from the position of world metropolis were met. Meanwhile in Skopje the rebuilding of the center

10 This is a well know page of the newest Macedonian history, so I decided to renounce providing references. However, an interesting view of ideological aspects and ideological and urbanistic approche can be found in Мирковски (2007). See also activities of Forum Skopje 2008. 
and the rather inconsistent breaking with continuity led to a landscape of contrasts and urban chaos. Some of the pieces realized in the spirit of the reconstruction plan are not in harmony with their surroundings; they eliminate the panorama, clashing, too, with the traditional architecture. The capital landscape created rather an image of an indecisive culture, torn between the desire for modernization and development in the Western spirit and attachment to tradition, understood here as the local, specific atmosphere of the city. As much as in the era of Haussmann benefits of consistency and state sponsorship enabled Paris to fully implement its designs, in Skopje the dominating impression made by the city's new form was fragmentation.

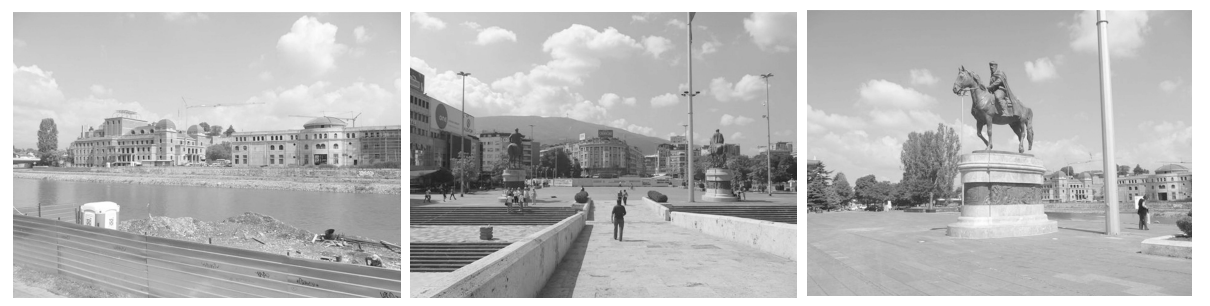

Fig. 5. The reorganization of the urban space of Skopje and new realizations in the city centre, from the left: construction of the National Theatre; an overview of the main square and two new monuments of national heroes, Dame Gruev and Goce Delčev; the monument of Dame Gruev (photographs by Jolanta Sujecka).

No doubt for this reason in Skopje in recent years a campaign to rebuild the city center has been undertaken. Its fundamental precepts are the rebuilding of several representative buildings around the main square (Плоштад Македонија). Among them are, in fact, a casino and a church from the interwar period. Partisans of the project emphasize that the goal of the project is the restoration of the city's local identity, the rebuilding of the spirit lost as a result of the violent interference in the coherent urban system after 1963. The residents need, after all, landmarks, specific to their own space and exclusive to it. The process of appropriation is founded upon the creation of safe frameworks for action where the most important thing is a sense of security, of being at home. A particular function is served by buildings that are either monuments or historical buildings, inscribed into the tradition of the city, testifying to continuity. They do not have to have a political dimension and even their real meaning or function does not impact the new network of significations - they simply become symbols of existence, of rootedness, of domesticated space. A violent change, like in the case of Skopje, may lead to the destruction of identification with the city as a space for quality being, which is after all the fundamental value of social space. The restitution of selected buildings may therefore be read as striving toward 
the filling in of the fragmentation of the Macedonian cultural imagination, the restitution of harmony between the field of the past and the temptation of modernity. A similar goal was aimed at with the renovations (or rather the new, modernized construction) of the Jabłonowski Palace in Warsaw at the Theatre Square: the building was destroyed during World War II and rebuilt only in the 90's. The facade of the palace completed the landscape of the square, which had been open until then, and because of that, less distinct. Nevertheless, the project of rebuilding the center of the Macedonian capital has not met with uniform support. It was accused of anachronism, of attempts to restore buildings with significance that is actually foreign to the Macedonian culture, connected with foreign domination. At the same time, the project would have the features of the next unsuccessful interference, leading to a deepening of the chaos of meanings (Буѓевац 2009; Biljali 2009; Мирковски 2008). In any case, the success of the plans will be judged by the reaction of the citizens accepting the new center within the mental map of the capital—or rejecting it because unable to identify with it.

It may be worthwhile in concluding to affirm once more the role of the state as the most important factor in the capital landscape. It is the bureaucracy of the state, appearing in the role of executor of the national will, deciding on the shape of the image of the city, reinforcing those values that seem to be desirable from the perspective of the represented group. The lack of that factor leads, as in the case of Skopje, to the preservation of the local past and/or to a haphazardly implemented, publicly sponsored construction. In both cases discussed above, the map and the landmarks mirror the most important categories of national narrative. The shape of this narrative depends largely upon the central authorities of the nation. ${ }^{*}$

\section{References}

Anderson B.

(1997) Wspólnoty wyobrażone, trans. S. Amsterdamski, Kraków.

Biljali

(2009) Biljali: Macedonia's ethnic balance at risk, interview by M. Stojanovska, available at http://www.setimes.com/cocoon/setimes/xhtml/en_GB/features/ setimes/articles/2009/06/08/reportage-01 (2010.03.21).

Буѓевац

(2009) Скопје ќе умре од невкуи, interview with Nebojša Viliќ, "Глобус. Неделен весник", 97.

${ }^{*}$ I would very much like to thank Jennifer Croft for translating this paper. 
Bromberger C., Ravis-Giordani G.

(2003) Espace donné, espace produit, esquisse d'une approche ethnologique, [in:] L'urbain et ses imaginaires, ed. P. Banchy and T. Paquot, Paris, pp. 13-26.

Castellan G.

(1991) Histoire des Balkans (XIVe-XXe siècle), Paris.

Castells M.

(2009) Społeczeństwo sieci, transl. M. Marody et al., Warszawa.

Deutsch L.

(2009) Métronome : L’histoire de France au rythme du métro parisien, Paris.

Đokić V.

(2004) Urbana morfologija: grad i gradski trg, Beograd.

Falski M.

(2008a) Porzadkowanie przestrzeni miejskiej. Przypadek chorwacki, Warszawa.

(2008b) Zawłaszczanie przestrzeni miejskiej a destrukcja kultury Bośni, „Slavia Meridionalis", 8, ed. G. Szwat-Gyłybow, Warszawa, pp. 137-154.

Gellner E.

(1991) Narody i nacjonalizm, transl. T. Hołówka, Warszawa.

Hannerz U.

(2006) Odkrywanie miasta: antropologia obszarów miejskich, Kraków.

Inalcik $\mathrm{H}$.

(2006) Imperium osmańskie: epoka klasyczna (1300-1600), transl. J. Hunia, Kraków.

Jałowiecki B.

(1988) Społeczne wytwarzanie przestrzeni, Warszawa.

Jałowiecki B., Szczepański M.

(2006) Miasto i przestrzeń w perspektywie socjologicznej, wyd. 2, Warszawa.

Jelavich B.

(2005) Historia Bałkanów, t. 1-2, Kraków.

Jezernik B.

(2007) Dzika Europa: Bałkany w oczach zachodnich podróżników, transl. P. Oczko, Kraków.

Lewis R.

(1984) Życie codzienne w Turcji osmańskiej, Warszawa.

Мирковски И.

(2007) Скопје требало да изгледа како Њујорк, “Теа модерна,” 2007.11.07.

(2008) Да учиме од настаните во минатото, но да гледаме напред, да ги следиме светските трендови, interview by С. Вукчевик, Порта3. "Градежништво, архитектура, екологија", бр. 86.

Raulin A.

(2001) Anthropologie urbaine, Paris.

Rossos A.

(2008) Macedonia and Maceonians. A History, Stanford University Press.

Stawowy-Kawka I.

(2000) Historia Macedonii, Wrocław.

Szacki J.

(1971) Tradycja: przegląd problematyki, Warszawa.

62 COLloquia Humanistica 
Wnuk-Lipiński E.

(2008) Socjologia życia publicznego, wyd. 2, Warszawa.

Zola É.

(1964) Au bonheur des dames, Paris ( $1^{\text {st }}$ ed. 1883).

\section{Ciągłość i nieciągłość w przestrzeni miasta stołecznego: Paryż i Skopje}

Przedmiotem niniejszego artykułu jest zagadnienie tworzenia wizji ciągłości dziejowej, a więc usensowionej narracji o przeszłości, w przestrzeni miasta. Miasto bowiem jawi się jako przestrzeń kulturowa par excellence i ono właśnie stwarza najlepsze możliwości wpływu na interpretację poprzez tworzenie specyficznego układu odniesień symblicznychi obrazów, pobudzających grę interpretacji. Miasto zamieszkiwane jest przez wiele jednostek i różnorakich grup, co zmusza je do negocjacji znaczeń. Przedmiotem przedstawionych tu badań są stolice. Stolica państwa to bowiem miasto szczególne, co zazwyczaj podkreśla sam status prawny ośrodka stołecznego regulowany przez specjalną ustawę, staje się niezwykle ważną przestrzenią symboliczną, miejscem pokazu państwowej i narodowej siły, eksponowania i utwierdzania tożsamości, prezentowania wizerunku obcym oraz kształtowania pożądanego wizerunku na użytek obywateli - członków swojej grupy. Na przykładzie Paryża i Skopja, miast o odmiennej kontekstowo historii, chciałbym pokazać specyficzne dla przestrzeni miejskiej sposoby indukowania interpretacji, albowiem mimo oczywistych różnic oba miasta pozwalają dostrzec historyczny okres, w którym samo miasto stało się istotnym składnikiem sfery publicznej i publicznej własności symbolicznej. Wzrost znaczenia miast w Europie wiąże się bez wątpienia z procesem demokratyzacji, zaś stolice Francji i Macedonii są dobrym przykładem tej przemiany, która przestrzeń sprywatyzowaną (feudalną) bądź interpretowaną w wymiarze sakralnym (jako ziemia należąca do Boga) przekształciła w przestrzeń publiczną, będącą dobrem wspólnym obywateli i/lub dominującego narodu. Najważniejszym agensem w przestrzeni stołecznej okazuje się państwo. To biurokracja państwowa, występująca w charakterze nosiciela woli narodu, decyduje o kształtowaniu wizerunku miasta, wzmacniając te wartości, które wydają się pożądane z perspektywy reprezentowanej grupy. Brak tego czynnika skutkuje, jak w przypadku Skopje, zachowaniem lokalności i/lub przypadkowością realizowanych inwestycji publicznych. W obu omawianych przypadkach mapa i punkty orientacyjne zdradzają najważniejsze kategorie narracji narodowej, a przecież za jej kształt w znacznym stopniu odpowiada właśnie władza centralna. 